\title{
CHANGES IN JOINT KINEMATICS IN CHILDREN WITH CEREBRAL PALSY WHILE WALKING WITH AND WITHOUT A FLOOR REACTION ANKLE-FOOT ORTHOSIS
}

\author{
Paulo Roberto Garcia Lucareli ${ }^{\mathrm{A}, \mathrm{C}}$, Mário de Oliveira Lima ${ }^{\mathrm{B}}$, Juliane Gomes de \\ Almeida Lucarellic ${ }^{\mathrm{C}}$, Fernanda Púpio Silva Lima ${ }^{\mathrm{B}}$
}

Lucareli PRG, Lima M de O, Lucarelli JG de A, Lima FPS. Changes in joint kinematics in children with cerebral palsy while walking with and without a floor reaction ankle-foot orthosis. Clinics. 2007;62(1):63-8.

INTRODUCTION: The floor reaction ankle-foot orthosis is commonly prescribed in the attempt to decrease knee flexion during the stance phase in the cerebral palsy (CP) gait. Reported information about this type of orthosis is insufficient.

PURPOSE: The purpose of this study was to determine the effect of clinically prescribed floor reaction ankle-foot orthosis on kinematic parameters of the hip, knee and ankle in the stance phase of the gait cycle, compared to barefoot walking on children with cerebral palsy.

METHODS: A retrospective chart review of 2200 patients revealed that 71 patients (142 limbs) had a diagnosis of diplegia, with no contractures in hip, knee or ankle flexion. Their average age was $12.2 \pm 3.9$. All of them were wearing clinically prescribed hinged floor reaction ankle-foot orthosis undergoing a three dimensional gait analysis. We divided the patients in three groups: Group I, with limited extension (maximum knee extension less than $15^{\circ}$ ); Group II, with moderate limited extension (maximum knee extension between $15^{\circ}$ and $30^{\circ}$ ) and Group III Crouch (maximum knee extension in stance more than $30^{\circ}$ ).

RESULTS: Results indicate the parameters maximum knee extension and ankle dorsiflexion were significant in Group II e III; no change was observed in Group I. The maximum hip extension was not significant in all three groups. Conclusion: when indicated to improve the extension of the knees and ankle in the stance of the CP patients floor reaction ankle-foot orthosis was effective.

KEYWORDS: Ankle-foot orthosis. Cerebral palsy. Gait. Kinematic.

\section{INTRODUCTION}

Spastic cerebral palsy is a common affliction encountered in all societies. Approximately 12,000 will suffer from this disability each year. The majority of children with cerebral palsy have the spastic physiologic variety. Approximately $85 \%$ of these children will use an orthosis. The most common orthosis used in spastic cerebral palsy is the ankle foot orthosis (AFO), which is available in many differ-

${ }^{\mathrm{A} C e n t r o ~ U n i v e r s i t a ́ r i o ~ S a ̃ o ~ C a m i l o ~-~ S a ̃ o ~ P a u l o / S P, ~ B r a z i l . ~}$

${ }^{B}$ Universidade do Vale do Paraíba - São José dos Campos/SP, Brazil.

${ }^{\mathrm{C}}$ Universidade Paulista - São Paulo/SP, Brazil.

Email: plucareli@hotmail.com

Received for publication on September 07, 2006.

Accepted for publication on September 25, 2006. ent designs. It is important that all professionals involved in the treatment of individuals with cerebral palsy have an understanding of this orthosis. Often in medical practice, theoretically sound treatments are employed, and then at a later date, a more critical scientific evaluation is carried out. This is especially true with the use of AFOs in the treatment of the spastic cerebral palsy.

The thermoplastic molded ankle-foot orthosis was first described in 1958 by Yates who used it in the treatment of a flaccid foot drop. ${ }^{1}$ Subsequently, it was used in children with cerebral palsy.

There are 4 main types of below-knee orthotics to improve function in gait. Each of these braces is made of lightweight plastic (usually polypropylene) and fits inside a conventional shoe. The 4 types are: 1) a UCBL (University of 
California Biomechanics Laboratory) —an in-shoe plastic slipper that controls functional varus and valgus deformities and, to some degree, supple malalignment of the hindfoot and midfoot; 2) a leaf-spring AFO_-a 1-piece, short leg brace that is usually made with the ankle in $5^{\circ}$ to $10^{\circ}$ of dorsiflexion and then ground back at the ankle to allow some flexionextension mobility; 3 ) a rigid AFO_-basically very similar to the leaf spring orthosis except that the ankle section is modeled in a neutral position and is left rigid. This orthosis is used to manage stance-phase deformities that are too strong to be controlled by a leaf-spring AFO; and 4) a floorreaction $\mathrm{AFO}$ - it is used to control second rocker. ${ }^{2}$

The first floor reaction AFO, designed by Al Masunis, was made at Newington Children's Hospital in 1983 as a modification of the Saltiel brace. ${ }^{3}$ There are currently 3 different designs of this orthosis. The first is the 1-piece, rigid ankle design; ${ }^{4}$ the second is a rigid ankle design with a removable anterior shell; and the third is a rear-entry, hinged design. Its major advantage is that it controls second rocker but does not interfere with first or third rocker, whereas the two earlier designs essentially eliminate ankle motion in stance. The major disadvantage of this brace is that it does not prevent equines in swing. ${ }^{2}$ One of the most common gait patterns in children with cerebral palsy is the crouch gait. There is increased knee flexion throughout the stance phase, with variable alignment in the swing phase (Figure 1).

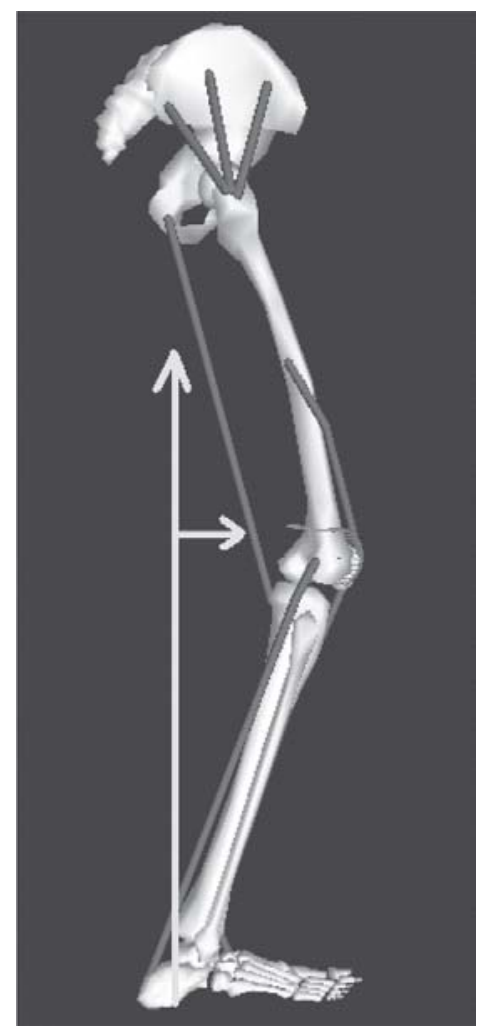

Figure 1 - Crouch Gait: increase knee flexion during stance phase and the external flexion moment
This condition is seldom found in children younger than 7 years of age. Primary contractures of the hamstrings, with or without contracture of the hip flexors, are the most common causes of crouch knee gait. This pattern may also be iatrogenic, such as primary hamstrings contractures seen after injudicious or isolated lengthening of contracted triceps surae.

The floor reaction ankle-foot orthosis (FRAFO) is commonly prescribed in an attempt to decrease knee flexion during the stance phase in the cerebral palsy gait, but prescription is often made clinically, not based on gait analysis.

Modern clinical gait analysis traces its origins back to the early 1980s with the opening of the laboratory developed by the United Technologies Corporation at Newington, Connecticut and those provided with equipment by Oxford Dynamics (later to become Oxford Metrics) in Boston, Glasgow, and Dundee. Retro-reflective markers were placed on the skin in relation to bony landmarks. These were illuminated stroboscopically and detected by modified video cameras. If 2 or more cameras detect a marker and the position and orientation of these cameras are known, then it is possible to detect the 3-dimensional position of that marker.

The purpose of this study was to determine the effect that a clinically prescribed floor reaction ankle-foot orthosis has on kinematic parameters of the hip, knee, and ankle in the stance phase of the gait cycle, compared to barefoot walking by children with cerebral palsy.

\section{METHODS}

A retrospective chart review of data collected between 1996 and 2004 in our motion analysis laboratory (Six Infra Red Cameras Vicon $370^{\circledR}$, Three AMTI Force Plates and 10 channels Motion Lab System EMG) was performed. A retrospective chart review of 2200 patients revealed 71 patients (142 limbs) with an average age of $12.2 \pm 3.9$ years. The inclusion criteria were cerebral palsy diagnosis type, spastic diplegia; walking with and without orthosis; having a clinically prescribed hinged FRAFO; and undergoing 3-dimensional gait analysis. The exclusion criteria were contractures of more than $10^{\circ}$ in hip and knee flexion and plantar-grade foot and malrotations of the foot or tibia. In accordance with our standard clinical practice, data for both conditions (brace and barefoot walking) were collected on the same day by the same examiner.

We divided the patients into 3 groups as follows: Group I-Limited extension (maximum knee extension less than $15^{\circ}$ ); Group II-Moderate limited extension (maximum knee extension between $15^{\circ}$ and $30^{\circ}$ ), and Group IIICrouch (maximum knee extension stance more than $30^{\circ}$ ) (Table 1). 
Table 1 - Design table of the patients into 3 groups based on knee range of motion during gait

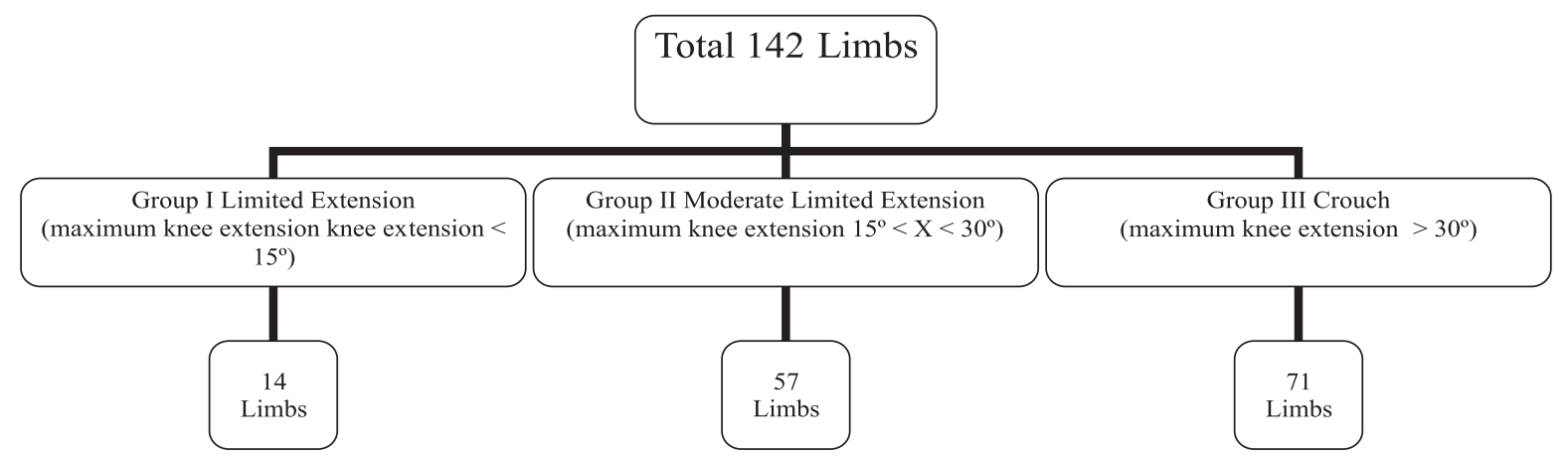

The maximum values of hip and knee extension and ankle dorsiflexion were extracted during the stance phase with and without FRAFO for each group.

\section{RESULTS}

Statistical analyses ( $t$ test) indicated the parameters maximum knee extension and ankle dorsiflexion were significant in Group II and III, and there was no change in Group I. The maximum hip extension was not significant in all 3 groups (Table 2).

\section{DISCUSSION}

This study supports the benefits of using hinged FRAFOs in children with spastic diplegic CP who exhibit a moderate or severe knee flexion (crouch gait) with excessive ankle dorsiflexion motion during the stance phase. Children wearing the FRAFO showed significant kinematic gait improvements including a reduction of abnormal ankle dorsiflexion and knee flexion motion. The hinged AFO produced significantly more normal ankle dorsiflexion motion and knee flexion, which has been one of the important benefits claimed by clinicians who recommend this orthosis.

Various ankle-foot orthoses (AFOs) have been used to correct the equinus gait pattern in children with spastic CP. ${ }^{8}$ The solid or fixed polypropylene AFO has been traditionally used to decrease equinus positioning and prevent an- kle plantar flexor contractures. ${ }^{5}$ A disadvantage of the solid AFO is its limitation of normal movement of the tibia forward over the weightbearing foot resulting in decreased ankle dorsiflexion and early heel rise in stance. ${ }^{6,7}$ The hinged or articulated polypropylene AFO with a plantar flexion stop has been increasingly recommended by clinicians to decrease equinus positioning. ${ }^{8}$ Unlike the solid AFO, the hinged AFO allows the tibia to move forward over the weightbearing foot during stance resulting in a more normal ankle dorsiflexion. ${ }^{6,8}$

Few published studies have examined the differences between these two types of orthoses during ambulation. Middleton et $\mathrm{al}^{9}$ compared the solid and hinged orthoses in a case study of one child with spastic diplegia and found reduced knee extensor moments during early stance and more normal ankle dorsiflexion motion after midstance with hinged AFOs. Rethlefsen et $\mathrm{al}^{10}$ compared gait with shoes and solid and hinged AFOs in children with spastic diplegic $\mathrm{CP}$, showing that dorsiflexion was greatest at terminal stance with the hinged AFO, but no differences in stride length or walking velocity were found.

This current study does not support previous findings 9,10 that the abnormal ankle plantar flexion motion during gait without orthosis was reduced with both solid and hinged AFOs. However, the excessive ankle dorsiflexion motion while barefoot ${ }^{11}$ was remedied by the FRAFO.

More ankle dorsiflexion than expected also occurred with the solid AFO due to the deformation of the

Table 2 - Mean value of the kinematic variables of hip, knee and ankle joints of patients with cerebral palsy with and without a floor reaction ankle-foot orthosis

\begin{tabular}{lllll}
\hline & $\mathrm{Nn}$ & HIP KINEMATICS & KNEE KINEMATICS & ANKLE KINEMATICS \\
\hline GROUP I & 14 & $17.7 \pm 14.8(P>0.05)$ & $6.1 \pm 9.4(P>0.05)$ & $9.5 \pm 6.5(P>0.05)$ \\
GROUP II & 57 & $19 \pm 20.7(P>0.05)$ & $15.7 \pm 10.2(P=0.0001)+$ & $11.5 \pm 9.0(P<0.05)^{*}$ \\
GROUP III & 71 & $41.2 \pm 19.9(P>0.05)$ & $37.6 \pm 11.4(P=0.0002)+$ & $4.2 \pm 7.6(P<0.01)^{*}$ \\
\hline
\end{tabular}

${ }^{+} P \mathrm{~d} \bullet 0.0001 ;{ }^{*} P<0.05$ 


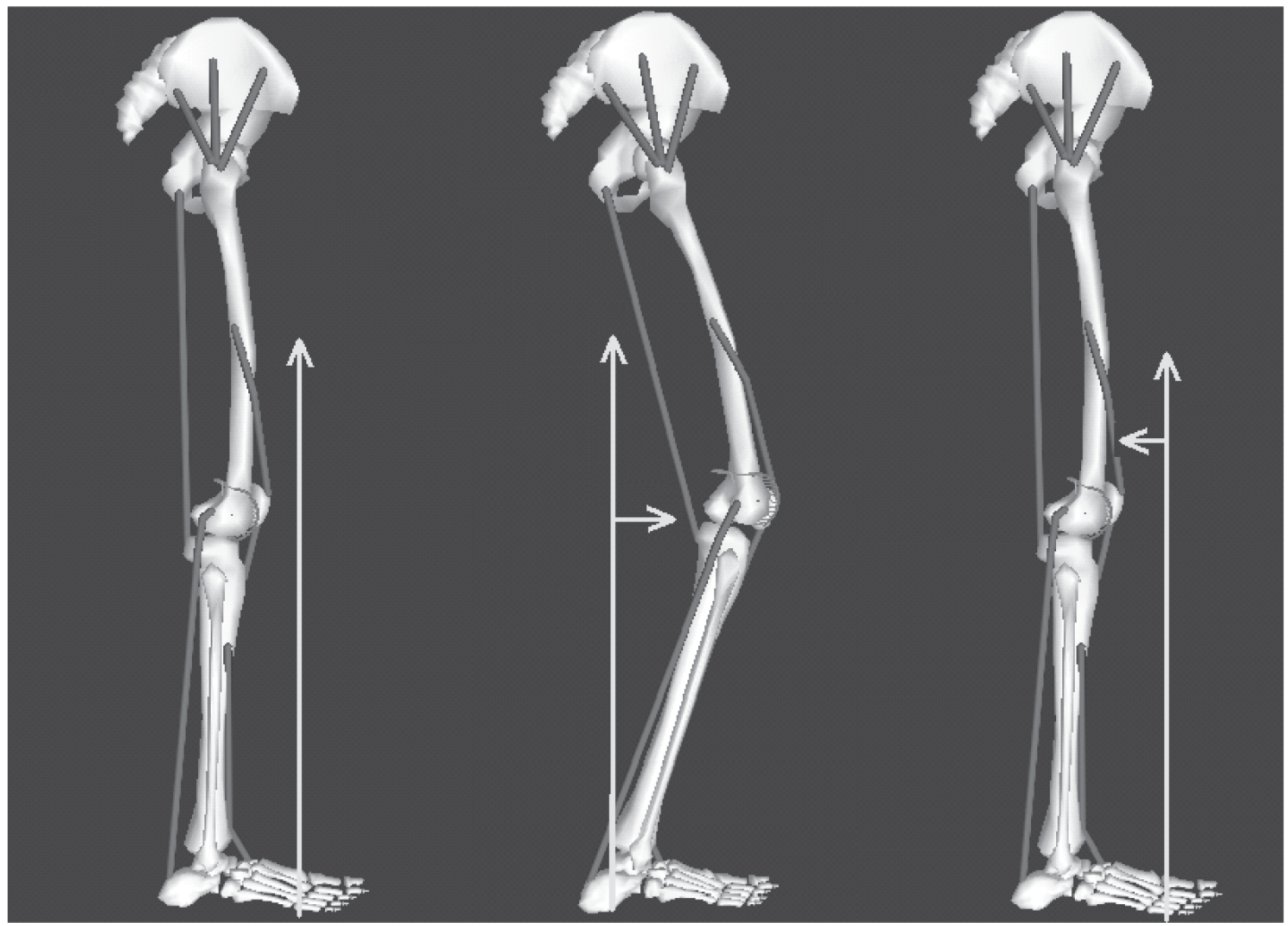

Figure 2 - The illustration of ground reaction force in normal gait, crouch gait and after the use of floor reaction

polypropylene material during weightbearing. ${ }^{12}$ Other studies of solid AFOs have also shown ankle dorsiflexion of 8 to 11.9 degrees during stance ${ }^{10,13,14}$ due to polypropylene deformation that occurs even with these rigid AFOs.

More normal dorsiflexion during TST was produced by the hinged AFO when compared to the solid AFO. These results confirmed previous research findings ${ }^{9,10}$ and clinicians' observations $^{6,8}$ that the solid AFO limits the normal forward progression of the tibia over the weightbearing foot, resulting in decreased ankle dorsiflexion and early heel rise. The hinged AFO has the advantage of allowing more normal dorsiflexion as the tibia transitions over the foot. ${ }^{11}$

Excessive knee flexion during stance was evident in subjects during barefoot gait. ${ }^{11}$ These abnormal knee motions were not changed with either hinged or solid AFOs as reported by Rethlefsen et $\mathrm{al}^{10}$ and Radtka et al. ${ }^{13}$ Clinicians' concerns regarding the possibility of more knee flexion for a crouched gait pattern as a result of hinged or solid AFOs were not substantiated. ${ }^{10}$ The increased knee extensor moments often seen in children with spastic $\mathrm{CP}^{15,16}$ were present in this study's subjects, which is possibly due to the FRAFO limiting the ankle dorsiflexion in the single support and consequently improving knee extension. The FRAFO provides a means of controlling or eliminating ankle and subtalar motion. By controlling the more distal joint, one can theoretically alter the ground reaction force and effect more proximal joints by the principal of the coupling.

Harrington et $\mathrm{al}^{17}$ and Gage ${ }^{18}$ report that the FRAFO limits the second rocker, improves knee extension, and consequently increases knee external extension moment (Figure 2).

Knee moments during stance were not changed in subjects wearing hinged or solid orthosis. The findings of Middleton et $\mathrm{al}^{9}$ of decreased excessive knee extension moments occurring during loading response with hinged AFOs as compared to solid AFOs in 1 child with spastic diplegic CP were not fully substantiated by this study.

It is important to know that the FRAFO probably will not improve kinematics if knee or hip flexion is a fixed deformity; whenever possible fixed deformities should be corrected prior to bracing for the principle of coupling to be effective. 
Group I did not present kinematic alterations, probably because the hip and knee flexion and ankle dorsiflexion were close to a normal gait.

No clinical studies have checked the effectiveness of FRAFO in patients with CP. Most studies discussed in this paper are based on solid or hinged ankle-foot orthoses (AFO) but not FRAFOs.

For future studies, it would be mandatory to correlate these results with physical exam, kinetics, and with electromyographs.

\section{CONCLUSION}

Floor reaction ankle-foot orthoses (FRAFO) were effective to improve the extension of the knees and ankle in the stance of children with spastic cerebral palsy.

\section{ACKNOWLEDGMENTS}

Special thanks to Wagner de Godoy for his friendship, help and knowledge support. Thanks the AACD Gait Laboratory and Gait Analysis Team.

\section{RESUMO}

Lucareli PRG, Lima M de O, Lucarelli JG de A, Lima FPS. Mudanças na cinemática articular em crianças com paralisia cerebral durante o andar com e sem órteses de reação ao solo. Clinics. 2007;62(1):63-8.

INTRODUÇÃO: A órtese de reação ao solo é freqüentemente prescrita com o objetivo de reduzir a flexão do joelho durante a fase de apoio na marcha de pacientes com paralisia cerebral. Não há informações suficientes relatadas na literature sobre este tipo de órteses.

OBJETIVOS: O objetivo deste estudo foi determinar o efeito que a órtese de reação ao solo tem na cinamática angular das articulações do quadril, joelho e tornozelo durante a fase de apoio da marcha de crianças com paralisia cerebral, comparando a marcha descalça e com o uso das órteses

MÉTODOS: Após um estudo retrospectivo de 2200 pacientes avaliados no laboratório de marcha, 71 pacientes com diagnóstico de paralisia cerebral do tipo diparesia espástica e idade média de $12.2 \pm 3.9$ foram selecionados (142 membros). Nenhum deles apresentou contratura em flexão dos quadris, joelhos e tornozelos. Todos usavam órteses do tipo reação ao solo articulada durante a avaliação da marcha. Os pacientes foram divididos em três grupos: Grupo I Extensão Limitada (pico de extensão do joelho menor que $15^{\circ}$ ); Grupo II Extenão Moderadamente Limitada (pico de extensão do joelho entre $15^{\circ}$ e $30^{\circ}$ ) e Grupo III Agachamento (pico de extensão do joelho no apoio maior que $30^{\circ}$ ).

RESULTADOS: Os resultados demostraram que o pico de extensão do joelho e o pico de dorsiflexão tiveram alterações significantes nos grupos II e III enquanto que o grupo I não apresentou alteração. $\mathrm{O}$ pico de extensão do quadril não mostrou alteração nos três grupos

CONCLUSÃO: A órtese de reação ao solo é eficaz quando indicada para aumentar a extensão do joelho e tornozelo durante a fase de apoio da marcha de crianças com paralisia cerebral

UNITERMOS: Órteses. Paralisia Cerebral. Marcha. Cinemática.

\section{REFERENCES}

1. Knutson LM, Clark DE. Orthotic devices for ambulation in children with cerebral palsy and myelomeningocele. Phys Ther. 1991;12:94752 .

2. Yates GA. Method for the provision of lightweight orthotic orthopedic appliance. Orthopedic Journal. 1958;1:53-57.
3. Gage JR. Gait analysis in cerebral palsy. Mac Keith Press: London; 1991.

4. Saltiel J. A one-piece, laminated, knee locking, short leg brace. Orthotics and Prosthetics. 1969;10:68-75. 
5. Meadows B. The influence of polypropylene ankle-foot orthoses on the gait of cerebral palsied children. University of Strathclyde, $\mathrm{PhD}$ dissertation in Gage JR. Gait analysis in cerebral palsy. Mac Keith Press: London; 1991.

6. Carmick J. Managing equinus in a child with cerebral palsy: merits of hinged ankle-foot orthoses. Dev Med Child Neurol 1995;37:1006-19.

7. Abel MF, Juhl CL, Damiano DL. Gait assesment of fixed ankle-foot orthoses in children with spastic diplegia. Arch Phys Med Rehabil 1998;79:126-33.

8. Knutosn L, Clark D. Orthotic devices for ambulation in children with cerebral palsy and myelomeningocele. Phys Ter 1991;71:947-60.

9. Middleton EA, Hurley GRB, Mcllwain JS. The role of rigid and hinged polypropylene ankle-foot-orthoses in the management of cerebral palsy: a case study. Prosthetics Orthotics Int 1988;12:129-35.

10. Rethelfsen S, Kay R, Dennis S, forstein M. Tolo V. The effects of fixed and articulated ankle-foot orthoses on gait patterns in subjects with cerebral palsy. J Pediatric Orthop 1999;19:470-4.

11. Freeman D, Orendurff M, Moor M. Case Study: Improving Knee Extension with Floor-Reaction Ankle-Foot orthoses in a Patient with Myelomeningocele and 20 Knee flexion Contractures. Journal of Prosthetics and Orthotics 1999;11:63-73.
12. Radtka SA, Skinner SR, Johanson ME. A comparison of gait with solid and hinged ankle-foot orthoses in children with spastic diplegic cerebral palsy. Gait Posture 2005;21:303-10.

13. Radtka SA, Skinner SR, Dixon DM, Johanson ME. A comparison of gait with solid, dynamic and no ankle-foot orthoses in children with spastic cerebral palsy. Phys Ther 1997;77:395-409.

14. Carlson WE, Vaughan CL, Damiano DL, Abel MF. Orthotic management of gait in spastic diplegia. Am J Phys Med Pehabil 1997;76:219-25.

15. Lai KA, Kuo KN, Andriacchi TP. Relationship between dynamic deformities and joint moments in children with cerebral palsy. J Pediatr Orthop 1988;8:690-5.

16. Radtka SA, Oliveira GB, Lindstrom Ke, Borders MD. The kinematic and kinetic effects of solid, hinged and no ankle-foot orthoses on stair locomotion in healthy adults. Gait Posture. 2006;24:211-8.

17. Harrington ED, Lin RS, Gage JR. Use of anterior floor reaction orthosis in patients with cerebral palsy. Orthotics and Prosthetics, 1984;4:3442.

18. Gage Jr. Treatment of gait problems in cerebral palsy. Mac Keith Press: London; 2004. 